\title{
INTELEGENSI DAN BAKAT PADA PRESTASI SISWA
}

\section{SALWA AFNIOLA, RUSLANA, WIWIT ARTIKA}

Universitas Syiah Kuala, Aceh

Email: salwaafniola@gmail.com,ruslan@unsyiah.ac.id,wartika@unsyiah.ac.id

\begin{abstract}
Abstrak
Kajian ini bertujuan untuk mengurai tentang intelegensi dan bakat pada prestasi siswa di pembelajaran di sekolah. Metode yang dilakukan pada kajian ini melalui studi pustaka dan juga literature research dengan hal-hal yang berkaitan dengan persoalan tersebut. Pembahasan pada kajian ini berdasarkan pada pendapat para ahli dan juga hasil penelitian terdahulu yang berkaitan dengan persoalan intelegensi dan bakat pada prestasi siswa. Belajar merupakan sesuatu yang mutlak harus dilakukan dalam pendidikan. Pendidikan merupakan upaya yang dilakukan untuk meningkatkan sumber daya manusia siswa dengan cara membimbing dan juga memberi fasilitas untuk proses belajar tersebut. Selama proses belajar terdapat hasil belajar yang didapatkan siswa dari proses belajar yang dilakukan dan dinilai oleh guru. Dari hasil belajar di sekolah didapatkan pencapaian prestasi siswa yang disebut juga dengan prestasi akademik. Ada banyak faktor yang mempengaruhi prestasi akademik dari seorang siswa, diantaranya terdapat faktor internal yaitu tingkat intelegensi dan juga bakat yang dimiliki oleh setiap siswa tersebut.
\end{abstract}

Kata kunci: Intelegensi, Bakat, Prestasi.

\begin{abstract}
This study aims to elaborate on intelligence and talent on student achievement in learning at school. The method used in this study is through literature study and also literature research with matters relating to the issue. The discussion in this study is based on the opinions of experts and also the results of previous research relating to the problem of intelligence and talent on student achievement. Learning is something that absolutely must be done in education. Education is an effort made to improve student human resources by guiding and also providing facilities for the learning process. During the learning process there are learning outcomes obtained by students from the learning process carried out and assessed by the teacher. From the results of learning in schools obtained student achievement which is also called academic achievement. There are many factors that affect the academic achievement of a student, including internal factors, namely the level of intelligence and talent possessed by each student.
\end{abstract}

Keywords: Intelligence, talent, achievement. 


\section{Pendahuluan}

Pada masa kini di era globalisasi tentu menuntut seseorang untuk menjadi salah satu sumber daya manusia yang berkualitas tinggi. Tingginya tingkat persaingan semakin membuat orang-orang berlomba-lomba untuk meningkatkan kualitas diri agar dapat menjadi salah satu dari sekian banyak orang-orang untuk mencapai tujuan pembangunan. Ada berbagai cara dalam meningkatkan kualitas sumber daya manusia, dan salah satu cara yang penting untuk meningkatkan hal tersebut adalah pendidikan. Pendidikan pada dasarnya merupakan salah satu aspek kehidupan atau usaha dasar bagi pembangunan. Pendidikan bertujuan untuk menumbuhkembangkan potensi dan juga kecerdasan untuk meningkatkan kualitas dari sumber daya manusia yang ada disuatu negara. Proses pendidikan dilakukan dengan melibatkan guru dan juga siswa sehingga terdapat proses pembelajaran yang juga didorong dengan adanya fasilitas untuk kegiatan belajar tersebut.

Belajar merupakan bagian paling penting dalam proses pendidikan karena sesungguhnya belajar merupakan hal mutlak yang harus dilakukan dalam pendidikan. Sehingga dapat dikatakan bahwa tanpa belajar maka tidak ada yang dapat disebut dengan pendidikan. Belajar sendiri merupakan suatu aktifitas untuk memperoleh ilmu pengetahuan. Ada banyak cara-cara belajar yang dapat diterapkan dalam kehidupan sehari hari yang semuanya bertujuan untuk meningkatkan kecerdasaan dan ilmu pengetahuan mempertahankan kehidupan diantara sekelompok manusia yang terus bersaing ketat dengan orang-orang atau bangsa-bangsa lainnya yang telah lebih dahulu maju karena pengaruh dari belajar. Belajar tidak hanya dapat dilakukan diruangan kelas, namun belajar dapat dilakukan dimana saja yang membuat seseorang mendapatkan wawasan atau ilmu pengetahuan dari tempat tersebut.

Dari proses belajar yang seringkali diperhatikan yaitu prestasi seorang siswa. Prestasi belajar atau prestasi akademik menurut Bloom merupakan ungkapan keberhasilan seseorang dalam hal belajar. Prestasi belajar juga diartikan sebagai hasil belajar seorang siswa yang dapat diketahui dengan melakukan tes-tes untuk menunjukkan prestasi belajar siswa tersebut. Prestasi belajar tersebut adalah salah satu bentuk penilaian pada usaha siswa dalam hal belajar dan guru yang menetapkan apakah usaha-usaha yang dilakukan oleh para siswa tersebut mencapai keberhasilan atau tidak. Prestasi belajar seringkali menjadi hal yang mendasar atau suatu patokan yang digunakan dalam menentukan bisa atau tidaknya seorang siswa dalam melakukan sesuatu, gagal atau suksesnya seseorang dan cerdas atau tidaknya siswa tersebut. Walaupun pada kenyataannya ada banyak faktor lain yang menjadi faktor untuk dapat mengukur suatu kecerdasaan dan keberhasilan seseorang.

Ada banyak faktor yang mempengaruhi prestasi siswa, namun secara garis besar faktor tersebut yaitu ada dua, yang pertama merupakan faktor internal yaitu 
berupa fisiologi dan juga psikologis. Selain faktor internal, faktor eksternal juga tentu termasuk dalam hal yang mempengaruhi prestasi seorang siswa. contoh dari faktor eksternal sendiri yaitu salah satunya adalah faktor lingkungan. Lingkungan sekitar tentu berperan sangat penting dalam prestasi seorang siswa karena tanpa sadar memberikan efek yang sangat melekat pada diri dan jiwa seseorang. Faktor eksternal terbagi menjadi faktor sosial dan juga non-sosial. Faktor sosial itu merupakan lingkungan terdekat dari seseorang, baik itu di lingkungan tempat ia tingga, dirumah mampun di lingkungan tempat ia belajar dan menuntut ilmu. Sedangkan faktor nonsosial itu dapat berupa lingkungan yang dapat dibuat atau secara fisik dapat dilihat dan dinikmati seperti lingkungan kamar siswa tersebut, atau tempat dia belajar dan juga tempat yang lain sebagainya.

Jika faktor internal yaitu faktor fisiologis seseorang itu berupa kesehatan seseorang yaitu kesehatan fisik yang menggunakan tubuh seperti tangan, kaki ataupun alat indra berupa mata, mulut, telinga dan juga lain sebagainya. Sedangkan untuk faktor psikologis ini lebih merujuk pada kemampuan dalam diri seseorang yaitu bisa berupa kemampuan bertalenta untuk menampilkan sesuatu atau bakat, kemauan dan juga kecerdasan yang dimiliki anak tersebut.

Intelegensi atau kecerdaan seseorang merupakan hal yang diyakini oleh para ilmuan merupakan salah satu faktor dari prestasi akademik seorang siswa. Intelegensi masuk dalam faktor internal yaitu pada faktor psikologis seseorang. Ada banyak sekali pemahaman dari intelegensi yang dikemukakan oleh para ahli, sehingga sampai saat ini definisi dari intelegensi sangatlah bermacam-macam. Kecerdasan intelegensi dapat berupa kemampuan siswa dalam menyesuaikan diri dengan suatu keadaan dengan sangat baik atau secara efektif dalam waktu yang cepat. Dari berbagai macam defenisi dari intelegensi yang dikemukakan oleh para ahli, dari waktu ke waktu hal tersebut terus menjadi perkembangan sehingga banyak mengalami perubahan kata atau maksud dari definisi tersebut namun juga tetap menekankan bagian kognitif dari seorang siswa.

Menurut Muhibbin Syah (2005) Intelegensi diartikan sebagai kemampuan psiko-fisik untuk merekasi rangsangan atau menyesuaikan diri dengan lingkungan dengan menggunakan cara yang tepat ${ }^{1}$. Jadi pada pernyataan ini dijelaskan bahwa intelegensi sebenarnya bukan hanya persoalan yang bersangkutan dengan fungsi kepala atau otak seseorang, tapi juga tentang persoalan bagaimana kondisi organ-organ yang ada diseluruh tubuh. Namun, tidak dapat dipungkiri bahwa tentu otak merupakan bagian yang paling penting dan lebih terlihat dominan perannya dari pada organ-organ tubuh yang lain karena dapat kita ketahui bahwa otak merupakan bagian dari tubuh manusia yang berfungsi untuk mengatur dan mengontrol hampir seluruh kegiatan yang dilakukan oleh manusia.

\footnotetext{
1 Muhibbin Syah, Psikologi Pendidikan Dengan Pendekatan Baru, (Bandung, PT Remaja Rosdakarya, 2005), h. 133.
} 
Salah satu cara yang digunakan dalam mengetahui tingkat integensi seseorang adalah dengan melakukan tes yaitu berupa tes yang menerjemahkan hasil-hasil dari tes intelegensi menjadi angka yang menjadi acuan atau sebagai suatu petunjuk mengenai tingkat tinggi atau rendahnya kecerdasan seorang siswa yang dibandingkan dengan nilai relatif yang tentu telah ditentukan sebelumnya. Tes untuk mengetahui tingkat kecerdasaan seseorang ini secara umum disebut dengan tes IQ (Intelligence Quotient). Intelegensi sebagai salah satu faktor dan juga aspek kognitif seseorang berperan penting pada tingkat prestasi seseorang. Hal ini dapat dilihat dari tingkat kecerdasan seorang siswa yang memiliki nilai IQ tinggi. Hal ini diakui oleh Luqman Gumadi dimana pada penelitiannya, ia menyimpulkan bahwa hubungan positif antara intelegensi dan juga prestasi seseorang itu adalah semakin tinggi nilai IQ seseorang, maka dapat semakin tinggi pula nilai prestasi orang tersebut. ${ }^{2}$

Selain intelegensi, bakat siswa juga merupakan hal yang sangat berpengaruh pada faktor belajar seorang siswa. Bakat merupakan sesuatu talenta yang banyak sekali yang dapat mencapai sebanyak manusia melakukan kegiatan atau suatu perbuatan individu. Dalam perkembangan yang semakin modern, definisi bakat sendiri semakin berkembang. Bakat diartikan sebagai kemampuan atau sesuatu yang dapat dilakukan seseorang sehingga ia dapat mencapai suatu keberhasilan di masa yang akan mendatang. Seiring perkembangan zaman hal ini kemudian di defenisikan sebagai kemampuan seseorang yang dapat melakukan suatu pekerjaan tertentu tanpa harus banyak dibantu oleh orang lain dengan upaya pendidikan dan juga latihan. Bakat dipercayai merupakan suatu kemampuan atau suatu potensi yang belum terpengaruh oleh pengalaman atau apapun yang masih menyangkut pada bagaimana kemungkinan untuk menguasai suatu dalam aspek kehidupan tertentu.

Dari pendapat para ahli, bakat diketahui dipengaruhi oleh tiga komponen yaitu intelektual, perseptual dan juga psikomotor. Pada setiap komponen ini terdiri lagi atas beberapa aspek yang merupakan hal penting dalam pembentukan suatu bakat. Tingkat tinggi dan juga rendahnya bakat seseorang tidak ditentukan dengan hanya melihat pada bagaimana keberadaan tiga komponen yang menjadi pengaruh besar pembentuk bakat, namun melihat pada bagaimana keterpaduan dan juga kualitas antara aspek-aspek tersebut. Selain itu, ada cara untuk mengetahui bagaimana tingkat bakat seseorang, yaitu dengan menggunakan tes bakat. Tes bakat ini pada umumnya merupakan tes baku yang disusun oleh para ahli pengukuran (Psychometrist). Ada beberapa tes bakat yang banyak digunakan dan terkenal di kalangan para ilmuan maupun masyarakat yaitu DAT, MT, MAT dan lain sebagainya. DAT atau yang lebih dikenal dengan

\footnotetext{
${ }^{2}$ Putra Putra, Hainul, Z. (2015). Hubungan Intelegensi Dengan Hasil Belajar Matematika Siswa Kelas V SD Negeri 68 Pekanbaru, JPM IAIN Antasari, 2(2), 1-18.
}

4| al-Din 
Differential Aptitude Test merupakan salah satu tes bakat yang sangat terkenal dan disusun oleh seorang ilmuan bernama Benet. Pada tes ini terdapat tujuh sub tes, yaitu bakat verbal, bilangan, berpikir abstrak, pemahaman hubungan ruang, bakat berpikir mekanis kecepatan dan juga ketelitian sampai bagaimana bakat seseorang dalam menggunakan suatu bahasa.

\section{METODE}

Metode yang digunakan dalam pengkajian mengenai intelegensi dan bakat pada prestasi siswa ini melalui studi pustaka yang dilakukan dengan mengkaji berbagai literature yang relevan dengan segala persoalan yang dibahas. Literatur yang pertama dilihat itu pada hasil penelitian yang dilakukan oleh para ilmuan dan juga akademisi, lalu selanjutnya dengan memperhatikan literature berupa artikel ilmiah yang dapat ditemukan di berbagai jurnal maupun proceeding seminar nasional maupun internasional. Literatur selanjutnya yaitu menggunakan berbagai bahan buku referensi dalam bentuk cetak maupun yang berbentuk salinan digital yang terkait dengan segala persoalan mengenai intelegensi dan bakat pada prestasi siswa ini. Dari hasil studi pustaka yang telah dilakukan ditemukan banyak literatur lalu di kelompokkan dan dicermati juga diringkas sehingga dapat menemukan hasil berupa substansi dari artikel-artikel ilmiah tersebut. Tahap berikutnya yaitu dengan menganalisis juga mengkaji lebih lanjut substansi artikel-artikel ilmiah yang didapatkan sehingga diperoleh pemahaman secara rinci dari setiap artikel tersebut. Selanjutnya yaitu dengan mengurai konsep dan teori dari artikel tersebut secara terperinci.

Langkah langkah yang dilakukan dalam studi pustaka untuk pengkajian mengenai Intelegensi dan Bakat Pada Prestasi Siswa yaitu dengan melakukan pengidentifikasian pada topik penelitian yang telah dilakukan para akademisi dan juga membaca bagian abstrak. Selanjutnya yaitu dengan membuat catatan dan juga ringkasan dari artikel ilmiah dan juga hasil dari membaca berbagai literatur yang didapatkan serta menyusun konsep dan juga teori yang berhubungan dengan intelegensi dan bakat pada prestasi siswa dan secara tematis menginterpretasikan pandangan dan pendapat yang berhubungan dengan pengkajian topik intelgensi dan bakat pada prestasi siswa.

\section{HASIL DAN PEMBAHASAN}

Menurut Sriyono Intelegensi merupakan kemampuan menerima dan memecahkan masalah adalah salah satu faktor yang menggerakkan siswa sehingga ia berhasil atau gagal dalam menghadapi lingkungan belajar nya. ${ }^{3}$ Integelensi merupakan

\footnotetext{
${ }^{3}$ Sriyono, Heru. (2016). Peran Tingkat Intelegensi dan Motivasi Belajar Dalam Meningkatkan Prestasi Belajar Ekonomi di SMA Negeri Gugus 01 Kabupaten Tangerang. Research and Development of Education, 3(1), 52-69.
} 
sebuah kemampuan belajar yang dapat dipengaruhi oleh berbagai faktor dan akan berpengaruh dari pada tingkat tinggi dan rendahnya kemampuan yang diterapkan siswa di dalam proses pembelajaran. Sedangkan bakat merupakan suatu kemampuan potensial yang dimiliki oleh seseorang untuk dapat mencapai suatu kesuksesan di masa depan. Bakat diartikan sebagai suatu potensi bawaan yang masih harus dikembangkan dan juga perlu dilatih sehingga dapat menjadi suatu potensi yang baik untuk modal seseorang di masa yang akan datang. Kemampuan bawaan jika dilatih maka akan dapat menghasilkan suatu keterampilan atau suatu kebisaan baik ilmu pengetahuan maupun kekreativitasan khusus seseorang dalam aspek atau bidang tertentu.

Intelegensi berhubungan dengan bakat. Siswa yang berbakat merupakan siswa yang cerdas yang tentunya mempunyai tingkat integensi yang tinggi. Kemampuan intelektual siswa juga merupakan salah satu hal yang mempengaruhi ketebakatan. Menurut para ilmuan siswa-siswi yang memiliki rentangan nilai IQ tinggi merupakan orang-orang yang berbakat tinggi juga memiliki talenta yang lebih dari pada siswa pada biasanya. Tentu kemampuan siswa ini juga berpengaruh besar pada hasil belajar atau prestasi siswa. Prestasi siswa adalah hasil belajar atau realisasi kemampuan potensial yang dicapai oleh siswa dalam kurun waktu tertentu. Seseorang tidak dapat mendapatkan suatu prestasi akademik atau hasil belajar yang baik begitu saja tanpa adanya usaha dan hal yang mendorong untuk dapat melakukan sesuatu sehingga akan mendapatkan prestasi belajar yang memuaskan. Faktor internal seperti intelegensi dan bakat seseorang juga berpengaruh pada prestasi akademik siswa.

Intelegensi dan bakat tentu sudah tidak diragukan lagi memiliki pengaruh pada prestasi siswa. Tingkat kecerdasaan atau kemampuan seseorang siswa sangat menentukan tingkat keberhasilan seorang siswa. Dengan kata lain, dapat diketahui bahwa semakin tinggi tingkat kecerdasaan dan kemampuan seorang siswa, berarti siswa tersebut juga akan mendapatkan peluang lebih besar untuk meraih kesuksesan dan juga sebaliknya apabila tingkat kecerdasan dan kemampuan seseorang rendah, berarti kecil pula peluang yang dimiliki oleh siswa tersebut untuk meraih sukses. Hal ini juga dinyatakan David Weschsler yang mendefenisikan bahwa intelegensi adalah kemampuan seseorang untuk bertindak dengan tujuan tertentu, berpikir secara rasional serta menghadapi lingkungannya dengan efektif. ${ }^{4}$ Dari pernyataan ini dapat dilihat bahwa intelengsi tentu berpengaruh signifikan pada prestasi atau hasil belajar seorang siswa.

${ }^{4}$ Rohmah, Umi. (2011). Tes Intelegensi dan Pemanfaatannya Dalam Dunia Pendidikan. Jurnal Cendekia, 9(1), 125-139.

6| al-Din 
Intelegensi mempengaruhi prestasi atau hasil belajar seorang siswa karena dapat kita ketahui bahwa siswa-siswi yang mempunyai tingkat kecerdasaan atau IQ yang tinggi akan terlihat lebih mudah belajar dan juga lebih cepat mengerti dan memahami pembelajaran yang diberikan oleh guru dan juga mendapatkan hasil yang baik pada prestasi belajarnya. Sebaliknya dengan siswa yang memiliki tingkat kecerdasaan atau intelegensi yang rendah, rata-rata memiliki kesulitan dalam belajar tidak cepat memahami pembelajaran yang dijelaskan sehingga prestasi yang didapatkannya juga cenderung rendah. Sehingga dapat dilihat bahwa tingkat intelgensi tentunya memberikan hasil positif pada prestasi belajar siswa.

Intelegensi atau kemampuan seseorang merupakan modal yang dapat membuat seseorang memiliki kemudahan dalam pembelajaran dan hal inilah yang membuat siswa tersebut dapat lebih mudah untuk mendapatkan prestasi akademik yang tinggi. Intelegensi membantu siswa dalam memecahkan permasalahan di lingkungannya sehingga siswa tersebut dapat dengan efektif menghadapi lingkungan belajarnya.

Selain itu bakat juga berpengaruh pada prestasi akademik siswa. Bakat akan mempengaruhi tingkat tinggi dan juga rendahnya prestasi seorang siswa pada aspek atau bidang-bidang tertentu. Bakat merupakan kecerdasan khusus yang dimiliki oleh seseorang. Tiap orang dapat memiliki jenis bakat yang berbeda-beda, yaitu ada yang memiliki bakat di bidang musik, olahraga, maupun dengan orang yang memiliki bakat numerik atau berhitung. Bakat akan sangat dapat membantu seseorang dalam kesuksesan di masa yang akan datang. Bakat adalah suatu potensial bawaan dimana jika dilatih dengan baik dan telaten maka dapat menjadi suatu keahlian seseorang dan dapat meraih kesuksesan. Bakat yang merupakan potensial khusus ini memiliki polapola perilaku masing-masing dalam pengembangannya. Seorang siswa yang memiliki tingkat keterbakatan yang tinggi akan lebih mampu dalam memamahami suatu informasi atau ilmu dan pengetahuan serta kemempuan yang berhubungan dengan persoalan dalam aspek tersebut daripada dengan siswa lain. Karena itu pelatihan khusus untuk mengembangkan bakat seorang siswa sangatlah dibutuhkan juga peran orangtua yang tentu sangat penting dan harus bijaksana dalam pengembangan bakat tersebut dan juga tidak memaksakan kehendak siswa tersebut untuk melanjutkan pendidikan pada bidang yang tidak disukai dan bukan pada keahlian atau kemampuan siswa tersebut tanpa persetujuan siswa itu sendiri. Karena kesalahan yang disebabkan olehe ketidakbijaksanaan ini dapat mempengaruhi prestasi akademik siswa tersebut.

Setiap siswa memiliki bakat masing-masing yang dapat mendukung mereka untuk berprestasi di bidang yang mereka mampu dan tekuni sesuai dengan kapasitas kemampuan masing-masing siswa tersebut. Jadi, secara umum dapat kita ketahui bahwa bakat itu hampir sama dengan intelegensi namun bakat merupakan kecerdasan khusus pada aspek dan bidang-bidang tertentu sedangkan intelengsi merupakan kecerdasan khusus yang tentu dimiliki oleh semua orang dengan tingkat yang berbeda beda. 
Namun pada kenyataannya, di ruang kelas dapat ditemui berbagai siswa dengan tingkat intelengensi dan bakat yang beragam. Terdapat anak-anak yang memiliki tingkat intelegensi dan keterbakatan yang tinggi sehingga tidak akan sulit untuk siswa tersebut dapat memahami pembelajaran di kelas. Terdapat juga siswa-siswi dengan tingkat intelegensi dan keterbakatan yang rendah yang tentunya siswa tersebut memiliki beberapa kesulitan dalam pembelajaran sehinga sulit untuknya memahami materi dan informasi yang diberikan guru di ruang kelas. Oleh karena itu, guru juga harus mengetahui bagaimana cara memperlakukan siswa-siswi dengan tingkat intelegensi yang beragam diruang kelas sehingga setiap siswa dapat memiliki prestasi belajar yang memuaskan.

Intelegensi dan bakat tentu memiliki pengaruh besar dalam tingkat kecerdasan dan kemampuan seorang siswa, namun hal ini tentu tidak menjadi faktor utama dalam menentukan keberhasilan dan kesuksesan seorang siswa. Intelegensi dan bakat sangat mempengaruhi prestasi akademik siswa, karena memiliki modal potensi yang memudahkan siswa tersebut untuk dapat memahami informasi dalam belajar sehingga dapat menghasilkan prestasi akademik yang tinggi dan optimal. Selain dari faktor internal yaitu intelegensi dan bakat, faktor lain juga tentu berpengaruh besar dalam prestasi akademik seorang siswa. Seperti motivasi belajar serta lingkungan yang mendukung. Kondisi intelektual seseorang juga dapat mempengaruhi keberhasilan dan prestasi seseorang yang menyangkut dengan kemampuan seperti bakat dan juga kemampuan seseorang serta kemampuan siswa dalam menguasai pengetahuan dan materi pembelajaran yang telah diberikan. Selain itu faktor dari luar diri siswa juga berpengaruh pada prestasinya seperti lingkungan sosial dan juga lingkungan masyarakatnya. Hal ini dapat mempegaruhi tingkat konsetrasi dari seorang siswa dalam belajar sehingga dapat berpengaruh besar dalam prestasi akademiknya di sekolah.

Selain itu, siswa-siswi yang belajar di sekolah dan melakukan kegiatan belajar untuk memperoleh pendidikan dan juga prestasi akademik yang memuaskan tentu didukung oleh orangtua dan guru juga dari lingkungannya untuk mendidik, memberi motivasi dan juga fasilitas sehingga siswa tersebut dapat belajar dengan baik dan mendapatkan prestasi yang optimal.

\section{KESIMPULAN}

Intelegensi dan bakat merupakan salah satu hal yang mempengaruhi prestasi akademik seorang siswa. Tingkat tinggi dan rendahnya intelegensi dan bakat dapat diukur untuk dapat memudahkan seseorang siswa mengetahui cara belajar dan talenta serta kemampuan yang dimilikinya. Rata-rata seorang siswa dengan keterbakatan yang tinggi juga memiliki tingkat intelegensi yang tinggi sehingga dapat memudahkan

8| al-Din 
dirinya untuk dapat mencapai keberhasilan dan memiliki kesempatan lebih besar untuk menjadi sukses. Sebaliknya, rata-rata siswa yang memiliki keterbakatan rendah juga memiliki tingkat intelegensi yang rendah sehingga membuat siswa tersebut sulit dalam hal pembelajaran di sekolah dan memiliki kemungkinan yang lebih kecil untuk dapat meraih sukses di masa yang akan datang. Namun intelgensi dan bakat merupakan merupakan faktor utama untuk dapat meraih kesuksesan karena ada banyak faktor lain yang dapat mempengaruhi suksesnya seseorang di masa yang akan datang.

\section{DAFTAR PUSTAKA}

Fadillah, Ahmad. (2016). Analisis Minat Belajar dan Bakat Terhdap Hasil Belajar Matematika Siswa. Jurnal Matematika dan Pendidikan Matematika. 1(2), 113122.

Huwaida, Nisrina, A. (2020). Pengaruh Intelegensi Dalam Pendidikan Anak. Jurnal Pendidikan dan Ilmu Sosial. 2(1), 42-49.

Jayantika, Trisna. (2013). Kontribusi Bakat Numerik, Kecerdasan Spasial, dan Kecerdasan Logis Matematis Terhadap Prestasi Belajar Matematika Siswa SD Negeri di Kabupaten Buleleng. E-Journal Program Pascasarjana Universitas Pendidikan Ganesha, 2(2), 1-12.

Muhibbin Syah. (2005). Psikologi Pendidikan Dengan Pendekatan Baru. PT Remaja Rosdakarya: Bandung.

Muthoharoh, Badriyatul, Nurul. (2016). Tingkat Intelegensi dan Peran Orangtua Terhadap Keterampilan Menulis Bahasa Inggris. Faktor Jurnal Ilmiah Kependidikan. 3(1), 35-46.

Pratiwi, Komari, N. (2015). Pengaruh Tingkat Pendidikan, Perhatian Orangtua, dan Minat Belajar Siswa Terhadap Prestasi Belajar Bahasa Indonesia Siswa SMK Kesehatan di Kota Tangerang. Jurnal Pujangga, 1(2), 75-105.

Putra, Hainul, Z. (2015). Hubungan Intelegensi Dengan Hasil Belajar Matematika Siswa Kelas V SD Negeri 68 Pekanbaru, JPM IAIN Antasari, 2(2), 1-18.

Razaq, Rahim, A. (2014). Interaksi Pembelajaran Efektif Untuk Berprestasi. Jurnal Pilar. 2(2), 122-136.

Rohmah, Umi. (2011). Tes Intelegensi dan Pemanfaatannya Dalam Dunia Pendidikan. Jurnal Cendekia, 9(1), 125-139.

Rufaidah, Anna. (2015). Pengaruh Intelegensi dan Minat Siswa Terhadap Putusan Pemilihan Jurusan. Faktor Jurnal Ilmiah Kependidikan. 2(2), 139-146.

Soemanto, Wasty. (1998). Psikologi Pendidikan Landasan Kerja Pemimpin Pendidikan. PT Rineka Cipta: Jakarta. 
Sriyono, Heru. (2016). Peran Tingkat Intelegensi dan Motivasi Belajar Dalam Meningkatkan Prestasi Belajar Ekonomi di SMA Negeri Gugus 01 Kabupaten Tangerang. Research and Development of Education, 3(1), 52-69.

Sukmadinata, Syaodih, N. (2003). Landasan Psikologi Proses Pendidikan. PT Remaja Rosdakarya: Bandung.

Supeni, M. G. (2011). Pengaruh Tanggung Jawab dan Intelegensi Terhadap Prestasi Belajar Siswa Kelas II IPS SMA EL Shadai TH. 2009/2010. Jurnal Penelitian Inovasi, 35(1), 102-115.

Thaib, Nauli, Eva. (2013). Hubungan Antara Prestasi Belajar Dengan Kecerdasan Emosional. Jurnal Ilmiah DIDAKTIKA. 13(2), 184-399.

Umar, Munirwan. (2015). Peranan Orangtua Dalam Peningkatan Prestasi Belajar Anak. Jurnal Ilmiah Edukasi, 1(1), 20-28.

10| al-Din 